\title{
An Evaluation of Mean Platelet Volume and Serum Lipid Profile in Patients with Fibromyalgia Syndrome
}

\author{
Fibromiyalji Sendromlu Hastalarda Ortalama Trombosit Hacminin ve \\ Lipid Parametrelerinin Değerlendirilmesi
}

\author{
Ayşe İYIYAPICI ÜNÜBOL, ${ }^{1}$ Gülnur TAŞCI BOZBAŞ, ${ }^{2}$ Mustafa ÜNÜBOL, ${ }^{3}$ Gülcan GÜRER ${ }^{4}$ \\ ${ }^{1}$ Department of Physical Medicine and Rehabilitation, Kuşadası State Hospital, Aydın, Turkey \\ ${ }^{2}$ Department of Physical Medicine and Rehabilitation, Aydin Medline Hospital, Aydin, Turkey \\ ${ }^{3}$ Department of Internal Medicine, Division of Endocrinology and Metabolism, Medical Faculty of Adnan Menderes University, Aydin, Turkey \\ ${ }^{4}$ Department of Physical Medicine and Rehabilitation, Division of Rheumatology, Medical Faculty of Adnan Menderes University, Aydin, Turkey
}

Objectives: This study aims to evaluate the mean platelet volume (MPV) and serum lipid profile in patients with fibromyalgia syndrome (FMS).

Patients and methods: This retrospective study was comprised of 156 patients with FMS and 118 healthy controls who were admitted to three centers between January 2011 and December 2011. The patients' fasting blood glucose, total cholesterol, low-density lipoprotein (LDL) and high-density lipoprotein (HDL) cholesterol, triglyceride levels and complete blood count, and MPV values were recorded. The Mann-Whitney $U$ test and Student's t-test were used according to the distribution of the data for statistical analysis.

Results: The experimental power of the study was found to be $100 \%(0.00063)$, when the effect size was taken as 0.6. The MPV value was $8.75 \pm 1.15 \mathrm{fL}$ in the patient group and $8.13 \pm 0.73$ in the healthy controls $(p<0.001)$. The serum triglyceride levels were significantly increased in the patients with FMS compared with the healthy controls $(p=0.003)$.

Conclusion: We found that the MPV, one of the early markers of atherosclerosis, was significantly high in the FMS patients.

Key words: Fibromyalgia syndrome; lipid; mean platelet volume; triglyceride.
Amaç: Bu çalışmada fibromiyalji sendromlu (FMS) hastalarda ortalama trombosit hacmi (OTH) ve serum lipid profili değerlendirildi.

Hastalar ve yöntemler: Bu retrospektif çalışma, Ocak 2011 - Aralık 2011 tarihleri arasında üç merkeze başvuran 156 FMS hastası ve 118 sağlıklı kontrolden oluşuyordu. Hastaların açlık kan glukoz, total kolesterol, düşük yoğunluklu lipoprotein (LDL) ve yüksek yoğunluklu lipoprotein (HDL) kolesterol, trigliserid düzeyleri ve tam kan sayımı ve OTH değerleri kaydedildi. İstatistiksel analiz için verilerin dağılım yapısına göre Mann-Whitney $U$ testi ve Student t-test kullanıldı.

Bulgular: Çalışmanın etki büyüklüğü 0.6 iken deneysel gücü, \%100 (0.00063) olarak hesaplandı. Ortalama trombosit hacmi, hasta grubunda $8.75 \pm 1.15 \mathrm{fL}$; sağlıklı kontrollerde $8.13 \pm 0.73$ idi $(p<0.001)$. Trigliserid düzeyleri, sağlıklı kontrollere kıyasla, FMS hastalarında anlamlı düzeyde artmıştı $(p=0.003)$.

Sonuç: Fibromiyalji sendromlu hastalarda aterosklerozun erken belirteçlerinden biri olan OTH'nin anlamlı düzeyde yüksek olduğu belirlendi.

Anahtar sözcükler: Fibromiyalji sendromu; lipid; ortalama trombosit hacmi; trigliserid.

\footnotetext{
Received: March 03, 2013 Accepted: May 03, 2013

Correspondence: Ayşe liyiyapıcı Ünübol, M.D. Kuşadası Devlet Hastanesi Fiziksel Tıp ve Rehabilitasyon Kliniği, 09400 Kuşadası, Aydın, Turkey.

Tel: +90 256 - 6182414 e-mail: aiyiyapici@yahoo.com 
Fibromyalgia syndrome (FMS) is a chronic rheumatic disease characterized by fatigue, diffuse pain, and tender points in certain anatomic regions and it has an unknown etiology. ${ }^{[1]}$ The prevalence rate is approximately $2 \%$ for the general population, $3.9 \%$ for women between 20 and 40 years old, and 5.8\% for women between 40 and 60 years. ${ }^{[2]}$ Although the etiopathogenesis for FMS has not yet been fully elucidated, various factors, including sleep irregularity, neuroendocrine dysfunction, changes in regional blood flow, and metabolic and immunological conditions, have been proposed. ${ }^{[1,3,4]}$ Generally, FMS may be associated with difficulty sleeping, nervousness, chronic fatigue, headaches, bowel and bladder syndrome, paresthesia, anxiety, and depression. ${ }^{[5-7]}$ In addition, pain and stress in patients with FMS chronically lead to an increase in sympathetic activity. ${ }^{[8,9]}$ Furthermore, chronic stress is thought to contribute to the risk of cardiovascular disease via the activation of the sympathetic nervous system and hypothalamo-pituitary-adrenal axis. ${ }^{[10]}$ There is also evidence to indicate that emotional stress triggers cardiovascular events. ${ }^{[1]]}$

Platelets play an important role in the pathophysiology of atherothrombotic disease. The mean platelet volume (MPV) includes the mean value of the volumes of platelets in the blood and is an indicator of platelet activation. ${ }^{[12-14]}$ In this study, we aimed to compare the MPV between a group of FMS patients and a healthy control group in order to evaluate the increased risk of cardiovascular disease associated with this condition.

\section{PATIENTS AND METHODS}

This retrospective study included 156 patients (150 females and 6 males; mean age $44.81 \pm 9.8$ years) with FMS and 118 healthy controls (113 females 5 males; mean age $47.71 \pm 16.5$ years) who were admitted to three centers between January 2011 and December 2011. A positive diagnosis of FMS was made in at least 11 of the 18 tender points (TPs) on a physical examination, and chronic pain ( $>3$ months) was present in four quadrants of the body, including the axillary region. ${ }^{[15]}$ Unfortunately, there is no specific laboratory or imaging method that can diagnose FMS, with the presence of diffuse TPs being the only physical examination finding and diagnostic criterion. ${ }^{[1,2,7]} \mathrm{A}$ TP is defined as the anatomic region where the patient feels pain when approximately $4 \mathrm{kgs}$ of pressure is applied. These points are located in the occiput, low cervical region, trapezius (TP), supraspinatus (SP), second rib, lateral epicondyle
(LE), gluteus (GL), greater trochanter (GT), and medial part of the knee. ${ }^{[15]}$

Patients who were using anticoagulant, antiaggregant drugs and those who had known congenital or acquired platelet disease, hemorrhagic disease, hematological disease, active infection, or acute stress were excluded from our study along with those with a history of cerebrovascular events, coronary artery disease (CAD), diabetes mellitus, or hypertension (HT) because these factors could affect the MPV. Additionally, patients taking antihyperlipidemic drugs were also not included. The thyroid-stimulating hormone (TSH) values of all of the patients were normal, and none had a history of thyroid disease. Furthermore, we also recorded the weight, height and body mass index (BMI) for all of the patients.

A laboratory analysis was also performed to assess the fasting blood glucose, total cholesterol (TC), low-density lipoprotein (LDL), high-density lipoprotein (HDL), and triglyceride (TG) levels along with the complete blood count (CBC) and MPV of the patients.

We calculated the MPV by averaging two different MPV values that were tested in venous blood samples containing ethylenediaminetetraacetic acid (EDTA) which were obtained at different times. In addition, we also determined this value after the diagnosis of FMS. The Coulter ${ }^{\circledR}$ LH 780 automated hematology analyzer (Beckman Coulter, Inc., Brea, CA, USA) was used to analyze the MPV, and a quality control analysis performed in our laboratory showed good reproducibility of the MPV measurement, with intra-assay and inter-assay coefficients producing a variation of $\leq 2.2 \%$ based on commercial controls. The ARCHITECT C8000 chemistry analyzer (Abbott Diagnostics, Lake Forest, IL, USA) was utilized to analyze the serum lipid parameters.

\section{Statistical analysis}

The SPSS version 16.0 for Windows software program (SPSS Inc., Chicago, IL, USA) was used to evaluate the data while the Mann-Whitney $U$ test and Student's t-test were used according to the distribution of the data for statistical measurements. As a result of a power analysis, the alpha margin of error was found to be 0.05 for our study. Additionally, the experimental power of the study was found to be $100 \%(0.00063)$ when the effect size was taken as 0.6 (mean MPV of $8.13 \pm 0.73$ for the control group and $8.75 \pm 1.15$ for the patient group). 
Table 1. A comparison of the numerical data between the patients with fibromyalgia syndrome and the control group

\begin{tabular}{|c|c|c|c|c|c|c|c|}
\hline & \multicolumn{3}{|c|}{ FMS group $(n=156)$} & \multicolumn{3}{|c|}{ Control group $(\mathrm{n}=118)$} & \multirow[b]{2}{*}{$p$} \\
\hline & $\mathrm{n}$ & Mean \pm SD & Min.-max. & $\mathrm{n}$ & Mean \pm SD & Min.-max. & \\
\hline Mean platelet volume (fL) & & $8.75 \pm 1.15$ & & & $8.13 \pm 0.75$ & & $<0.001^{\star}$ \\
\hline Age (years) & & $44.81 \pm 9.8$ & & & $47.71 \pm 16.5$ & & $>0.05^{\star}$ \\
\hline Body mass index $\left(\mathrm{kg} / \mathrm{m}^{2}\right)$ & & $26.39 \pm 3.48$ & & & $25.8 \pm 2.82$ & & $>0.05^{\star}$ \\
\hline Low-density lipoprotein (mg/dl) & 118 & & $89.25-141$ & 123 & & $107-149$ & $>0.05^{\star *}$ \\
\hline Triglyceride (mg/dl) & 114 & & $100.3-192.8$ & 106 & & $82-125.5$ & $0.003^{\star *}$ \\
\hline High-density lipoprotein (mg/dl) & & $44.12 \pm 8.36$ & & & $44.17 \pm 8.98$ & & $>0.05^{\star}$ \\
\hline Fasting venous glucose (mg/dl) & 92 & & $84-99$ & 91 & & $84-95$ & $>0.05^{\star *}$ \\
\hline Hemoglobin $(\mathrm{g} / \mathrm{dL})$ & & $13.02 \pm 0.93$ & & & $13.03 \pm 0.66$ & & $>0.05^{\star}$ \\
\hline White blood cell count $\left(/ \mathrm{mm}^{3}\right)$ & & $6998 \pm 1275$ & & & $6708 \pm 1201$ & & $>0.05^{\star}$ \\
\hline Platelet $\left(/ \mathrm{mm}^{3}\right)$ & & $270560 \pm 66939$ & & & $273370 \pm 62434$ & & $>0.05^{\star}$ \\
\hline
\end{tabular}

\section{RESULTS}

There were no statistically significant differences regarding age and gender in the FMS and control groups ( $\mathrm{p}>0.05)$. Twenty-four patients in the FMS group were smokers, but no significant difference between the two groups with respect to smoking was noted ( $>0.05)$. The mean body mass index (BMI) was $26.39 \pm 3.48 \mathrm{~kg} / \mathrm{m}^{2}$ in the patient group, which was not statistically significantly different from the control group ( $p>0.05$ ). In addition, the mean BMI value was between 25 and $29.9 \mathrm{~kg} / \mathrm{m}^{2}$, and this was considered to be "overweight". The MPV value was $8.75 \pm 1.15 \mathrm{fL}$ in the patient group and $8.13 \pm 0.73$ in the healthy control group, and the difference between the two groups was statistically significant $(\mathrm{p}<0.001)$. However, there was no correlation between the BMI and MPV in the FMS group $(r=-0.019, p=0.817)$. Furthermore, the mean number of tender points was $14.74 \pm 2.61$ in the patient group at the time of diagnosis.

\section{DISCUSSION}

A limited number of studies have evaluated the increased risk of atherosclerosis in patients with FMS, and there is insufficient information concerning MPV in patients with FMS in the literature.

In a study performed by Lee et al., ${ }^{[16]}$ arterial stiffness was found to be increased in patients with FMS, and they proposed that there was a relationship between FMS and endothelial dysfunction. In another study by Cho et al., ${ }^{[17]}$ patients with FMS were evaluated based on their response to brachial artery flowmediated dilatation, and a decrease in endothelial function was seen. In addition, Ablin et al., ${ }^{[18]}$ evaluated patients with CAD and normal coronary arteries on coronary angiography in terms of FMS and found that those with CAD had significantly higher rates of FMS. In their study in which FMS patients who were hospitalized between 1997 and 2007 were evaluated, Haviland et al. ${ }^{[19]}$ discovered that the most common primary diagnoses were essential HT, lipid metabolism disorders, coronary atherosclerosis and other heart diseases, and mental disorders, with FMS being a secondary diagnosis.

Mean platelet volume, which is a marker for platelet activation, is a new risk indicator for atherothrombosis since increased platelet activity has been shown to contribute to the rise in the risk of cardiovascular disease associated with impaired glucose tolerance. ${ }^{[20]}$ Ünübol et al. ${ }^{[12]}$ determined that there was a relationship between microalbuminuria, an indicator of microangiopathy, and MPV in type 2 diabetes patients. In studies performed involving patients with CAD, an increase in MPV was reported. Martin et al. ${ }^{[21]}$ measured the MPV in 1,716 patients who had myocardial infarctions (MIs) and found that it was significantly increased in the those who had had recurrent ischemic attacks that led to their deaths two years later. The authors also showed that MPV is an independent risk factor for recurrent MI. Moreover, it has been reported that an increase in platelet volume occurs with acute MI, acute cerebral ischemia, and transient ischemic attacks. ${ }^{[22]}$ Futhermore, Han et al. ${ }^{[23]}$ reported that MPV is a predictive marker for stroke or CAD, and Greisenegger et al. ${ }^{[24]}$ determined that an elevated MPV is associated with a poorer outcome for acute ischemic cerebrovascular events independent of other clinical parameters. Previous studies have also reported that high MPV levels are related with cardiovascular risk 
factors $^{[25]}$ and that these levels increase in patients with cardiac conditions ${ }^{[26-28]}$ who have a poor prognosis.

Lipid parameters, which are cardiovascular risk factors, have also been evaluated in patients with FMS in various studies. Gurer et al., ${ }^{[29]}$ determined that the LDL value in patients with FMS was significantly higher compared with the control group. However, in a study by Özgöçmen et al., ${ }^{[30]}$ the serum TG, HDL, LDL, and TC levels in patients with FMS did not significantly differ from the control group. In our study, the LDL, HDL, and fasting venous glucose values were not statistically significantly different compared with the control group, but the serum TG levels were significantly higher in those with FMS. In addition, the patients who were deemed to be "overweight" according to the BMI were at a higher risk for cardiovascular disease and had higher TG levels than the control group. Okifuji et al ${ }^{[31]}$ reported that approximately $50 \%$ of the FMS patients in their study were obese, and $21 \%$ were "overweight", which are higher percentages than are present in the normal population. They also commented that their results provided a preliminary indication that obesity may play some role in FMS-related dysfunction. Bardal et al. ${ }^{[32]}$ reported that reduced aerobic capacity in patients with FMS. We think that reduced physical activity may be affecting the serum TG levels and BMI in this painful syndrome.

\section{Conclusion}

In this retrospective study, we determined that there were increased BMI levels in the patients with FMS, indicating that they had high levels of TG and an increased risk for cardiovascular disease. We also found that the FMS patients had a high MPV. However, further prospective studies that focus on MPV should be undertaken to accurately determine the actual risk for cardiovascular disease in patients with FMS.

\section{Declaration of conflicting interests}

The authors declared no conflicts of interest with respect to the authorship and/or publication of this article.

\section{Funding}

The authors received no financial support for the research and/or authorship of this article.

\section{REFERENCES}

1. Forseth KO, Gran JT, Husby G. A population study of the incidence of fibromyalgia among women aged 26-55 yr. Br J Rheumatol 1997;36:1318-23.
2. Wolfe F, Ross K, Anderson J, Russell IJ, Hebert L. The prevalence and characteristics of fibromyalgia in the general population. Arthritis Rheum 1995;38:19-28.

3. Güleç H, Sayar K, Yazici Güleç M. The relationship between psychological factors and health care-seeking behavior in fibromyalgia patients. [Article in Turkish] Turk Psikiyatri Derg 2007;18:22-30.

4. Altındağ Ö. Fibromiyaljide nöroendokrin işlev bozuklukları. Turk J Rheumatol 2009;24:98-102.

5. Russell AS, Gervais R. Cognitive function in fibromyalgia: comment on the article by Park et al. Arthritis Rheum 2002;46:1980.

6. Cho KI, Lee JH, Lee HG, Kim SM, Kim TI. Assessment of myocardial function in patients with fibromyalgia and the relationship to chronic emotional and physical stress. Korean Circ J 2010;40:74-80.

7. McCarberg B, Barkin RL, Wright JA, Cronan TA, Groessl E, Schmidt SM. Tender points as predictors of distress and the pharmacologic management of fibromyalgia syndrome. Am J Ther 2003;10:176-92.

8. Giske L, Vøllestad NK, Mengshoel AM, Jensen J, Knardahl $\mathrm{S}$, Røe C. Attenuated adrenergic responses to exercise in women with fibromyalgia--a controlled study. Eur J Pain 2008;12:351-60.

9. Martinez-Lavin M. Biology and therapy of fibromyalgia. Stress, the stress response system, and fibromyalgia. Arthritis Res Ther 2007;9:216.

10. McEwen BS. Protective and damaging effects of stress mediators: central role of the brain. Dialogues Clin Neurosci 2006;8:367-81.

11. Tofler GH, Muller JE. Triggering of acute cardiovascular disease and potential preventive strategies. Circulation 2006;114:1863-72.

12. Ünübol M, Ayhan M, Güney E. The relationship between mean platelet volume with microalbuminuria and glycemic control in patients with type II diabetes mellitus. Platelets 2012;23:475-80.

13. Butterworth RJ, Bath PM. The relationship between mean platelet volume, stroke subtype and clinical outcome. Platelets 1998;9:359-64.

14. Trowbridge EA, Martin JF. The platelet volume distribution: a signature of the prethrombotic state in coronary heart disease? Thromb Haemost 1987; 58:714-7.

15. Wolfe F, Smythe HA, Yunus MB, Bennett RM, Bombardier C, Goldenberg DL, et al. The American College of Rheumatology 1990 Criteria for the Classification of Fibromyalgia. Report of the Multicenter Criteria Committee. Arthritis Rheum 1990;33:160-72.

16. Lee JH, Cho KI, Kim SM, Lee HG, Kim TI. Arterial stiffness in female patients with fibromyalgia and its relationship to chronic emotional and physical stress. Korean Circ J 2011;41:596-602.

17. Cho KI, Lee JH, Kim SM, Lee HG, Kim TI. Assessment of endothelial function in patients with fibromyalgia--cardiac ultrasound study. Clin Rheumatol 2011;30:647-54. 
18. Ablin JN, Beilinson N, Aloush V, Elkayam O, Finkelstein A. Association between fibromyalgia and coronary heart disease and coronary catheterization. Clin Cardiol 2009;32:E7-11.

19. Haviland MG, Banta JE, Przekop P. Fibromyalgia: prevalence, course, and co-morbidities in hospitalized patients in the United States, 1999-2007. Clin Exp Rheumatol 2011;29:S79-87.

20. Coban E, Kucuktag S, Basyigit S. Platelet activation in subjects with impaired glucose tolerance. Platelets 2007;18:591-4.

21. Martin JF, Bath PM, Burr ML. Influence of platelet size on outcome after myocardial infarction. Lancet 1991;338:1409-11.

22. Bath PM, Missouris CG, Buckenham T, MacGregor GA. Increased platelet volume and platelet mass in patients with atherosclerotic renal artery stenosis. Clin Sci (Lond) 1994;87:253-7.

23. Han JY, Choi DH, Choi SW, Kim BB, Ki YJ, Chung JW, et al. Stroke or coronary artery disease prediction from mean platelet volume in patients with type 2 diabetes mellitus. Platelets 2013;24:401-6.

24. Greisenegger S, Endler G, Hsieh K, Tentschert S, Mannhalter C, Lalouschek W. Is elevated mean platelet volume associated with a worse outcome in patients with acute ischemic cerebrovascular events? Stroke 2004;35:1688-91.
25. Tsiara S, Elisaf M, Jagroop IA, Mikhailidis DP. Platelets as predictors of vascular risk: is there a practical index of platelet activity? Clin Appl Thromb Hemost 2003;9:177-90.

26. Endler G, Klimesch A, Sunder-Plassmann H, Schillinger $\mathrm{M}$, Exner M, Mannhalter $\mathrm{C}$, et al. Mean platelet volume is an independent risk factor for myocardial infarction but not for coronary artery disease. $\mathrm{Br} \mathrm{J}$ Haematol 2002;117:399-404.

27. Bitigen A, Tanalp AC, Elonu OH, Karavelioglu Y, Ozdemir N. Mean platelet volume in patients with isolated coronary artery ectasia. J Thromb Thrombolysis 2007;24:99-103.

28. Celik T, Yuksel UC, Bugan B, Iyisoy A, Celik M, Demirkol $\mathrm{S}$, et al. Increased platelet activation in patients with slow coronary flow. J Thromb Thrombolysis 2010;29:310-5.

29. Gurer G, Sendur OF, Ay C. Serum lipid profile in fibromyalgia women. Clin Rheumatol 2006;25:300-3.

30. Ozgocmen S, Ardicoglu O. Lipid profile in patients with fibromyalgia and myofascial pain syndromes. Yonsei Med J 2000;41:541-5.

31. Okifuji A, Bradshaw DH, Olson C. Evaluating obesity in fibromyalgia: neuroendocrine biomarkers, symptoms, and functions. Clin Rheumatol 2009;28:475-8.

32. Bardal E, Olsen T, Ettema G, Mork P. Metabolic rate, cardiac response, and aerobic capacity in fibromyalgia: a case-control study. Scand J Rheumatol 2013. [Epub ahead of print] 